\section{FLAMMARION MÉDECINE-SCIENCES}

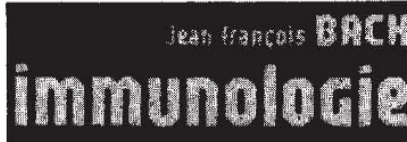

\section{Immunologie}

J.F. BACH et Ph. LESAVRE De façon claire, directe et très illustrée, les principales connaissances modernes de l'immunologie fondamentale et de l'immunopathologie. 1981, broché, 328 p., 198 fig., $185,00 \mathrm{FF}$.
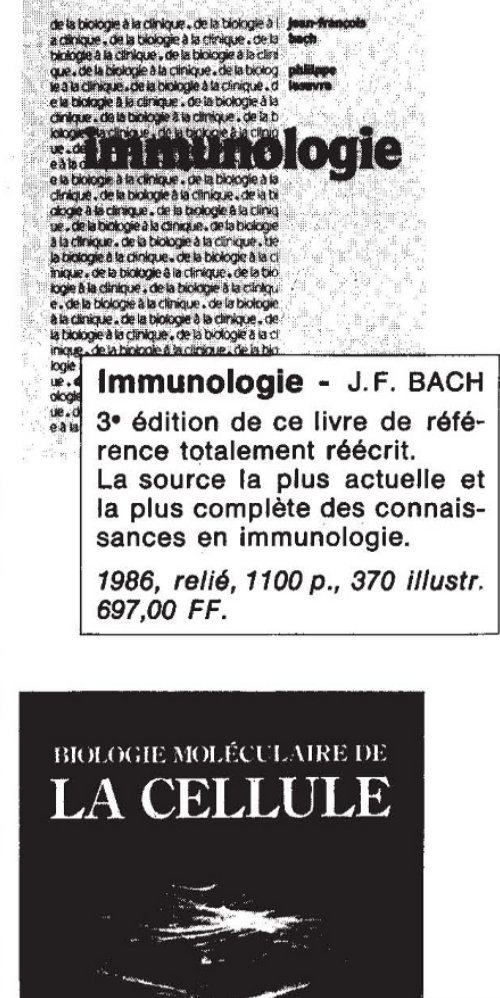

Biologie Moléculaire de la Cellule.

B. ALBERTS, D. BRAY, J. LEWIS, M. RAFF, K. ROBERTS, J. WATSON

Traduction française du célèbre ouvrage américain. Rend compte, de façon exhaustive, de toutes les connaissances actuelles sur la Cellule à un niveau très approfondi.

1986, 1300 illustr. en 2 coul., édition brochée: $620,00 \mathrm{FF}$ édition reliée: $695,00 \mathrm{FF}$.

\section{4, rue Casimir-Delavigne 75006 PARIS} \section{Men and machines remembered}

\section{J.M.M. Pinkerton}

Memoirs of a Computer Pioneer. By Maurice Wilkes. MIT Press:1985. Pp.240. $\$ 19.95, £ 19.95$.

ELECTRONIC computing and communications technologies are of indisputable social and economic importance. To anyone in the field, and many outside it, the history of their development recorded by one of the innovators must be of the greatest interest. Professor Wilkes's book, part of a historical series published by MIT Press, is therefore likely to find a large and receptive audience.

About half of the book deals with the author's family background, his education, his radio research at the Cavendish Laboratory before the war under J.A. Ratcliffe and at the Mathematical Laboratory in Cambridge, and his varied wartime activities as a government radar scientist. All this experience was in fact invaluable, not only because many of the electronic techniques used for radar were readily adapted to the design of early computers, but because Wilkes had become familiar with problems and methods of computation for which computers were suitable.

A fascinating chapter describes the conception, planning and successful construction of EDSAC 1 in the Mathematical Laboratory in the years 1946 to 1949. Wilkes records this in such straightforward terms as almost to belittle the achievement. He carefully acknowledges where due his indebtedness to others for inspiration - to John von Neumann; to speakers on the course at the Moore School of the University of Pennsylvania in 1946, when a variety of techniques were proposed to build a working computer; to the Eckert-Mauchly report proposing a design for EDVAC; and, especially, to Douglas Hartree.

As the series editors say in their foreword, Wilkes aimed not merely to build a machine that would work, but also to investigate programming as an art and an intellectual process applicable to problems, for example in physics, whose numerical solution called for extended computation. While scientists at Cambridge were using the differential analysers, originally developed by Hartree at Manchester and already installed in Wilkes's laboratory, it was anticipated that EDSAC would be faster and better in all respects. With Wheeler and Gill, Wilkes was the first to write subroutines and incorporate them in programs, and a library of subroutines was quickly assembled for programmers' use. Even before EDSAC was finished, much thought had been given to feeding decimal numbers in and out; for scientific work, the simple paper tape and teleprinter combination adopted was reasonably well matched to EDSAC's arithmetic speed.

Remarkably soon after EDSAC successfully ran programs, Wilkes started to teach others how to develop them, very much in the tradition of the Cavendish Laboratory. Ratcliffe, whose guidance in his earlier career Wilkes acknowledges, used to say that no research was complete until it had been taught, not just published. The course first given in 1950 , was the basis of the first book on programming ever to appear - The Preparation of Programs for an Electronic Digital Computer, with Special Reference to the EDSAC and the Use of a Library of Subroutines (Addison-Wesley, 1951), which was re-printed by Tomash and MIT Press in 1982.

After starting an informal computing service, based on EDSAC, for the whole University, Wilkes began to design EDSAC2. This was to be a parallel machine retaining the ultrasonic memory, though in the event core memories were invented in time. A major innovation was microprogramming, a concept Wilkes first described in 1951 and which, of course, has since had a profound influence on computer design.

In the book Wilkes refers to the key contribution he made in the early $1950 \mathrm{~s}$ to the LEO project (Lyons Electronic Office, the first computer built specifically for clerical work) and later, obliquely, to his present job with Digital Equipment Corporation. But he says little about the guidance he gave as Director of the Cambridge Computer Laboratory until he moved to the United States in 1980 , not only to his students but to anyone else who asked for it, as many did.

The book concludes with chapters on more recent developments on both sides of the Atlantic, with many of which Wilkes was involved (for example use of capabilities and the Cambridge Ring LAN). In sum, this is a straightforward personal account, clearly and readably. told; it represents a notable contribution to the early history of ideas and practice in digital computing, as they have evolved throughout the world.

J.M.M. Pinkerton, formerly Manager, Strategic Requirements, with ICL, now runs an information-technology consultancy, McLean Pinkerton Associates, 2 Sandown Road, Esher, Surrey K109TU, UK.

- Recently published by Morgan Kaufmann is Machine Learning: An Artificial Intelligence Approach, Vol.II. edited by Ryszard S. Michalski, Jaime G. Carbonell and Tom M. Mitchell. Distributor is W.H. Freeman, price is $\$ 39.95$. $£ 39.95$. The previous volume was reviewed by Margaret Boden in Nature 308, 89 (1984). 